\title{
水俣湾における海水中の水銀の形態と 輸送に関する現地調査 \\ IN-SITU MEASUREMENT OF MERUCRY FORM AND TRANSPORT IN THE SEA WATER OF MINAMATA BAY
}

\author{
矢野真一郎 $1 \cdot$ 田井明 $2 \cdot$ 矢野康平 $3 \cdot$ 松山明人 4 \\ 藤原竜二 5 ・多田彰秀 6 ・園田育子 7 . Herawaty RIOGILANG ${ }^{8}$ \\ Shinichiro YANO, Akira TAI, Kohei YANO, Akito MATSUYAMA, \\ Ryuji FUJIWARA, Akihide TADA, Ikuko SONODA and Herawaty RIOGILANG
1正会員 博（工）九州大学大学院准教授 工学研究院環境都市部門（广819-0395 福岡市西区元岡744）
2正会員 博 (工) 九州大学大学院特任助教 工学研究院環境都市部門（同上）
3 学生員 九州大学大学院 工学府海洋システム専攻 (同上)
4正会員 博 (農) 環境省国立水俣病総合研究センター 疫学研究部（广867-0008 水俣市浜4058-18）
5 学生員 長崎大学大学院 生産科学研究科環境システム工学専攻（广852-8521 長崎市文教町1-14)
6 正会員 博 (工) 長崎大学大学院教授 工学研究科システム科学部門（同上）
7 非会員 環境省国立水俣病総合研究センター 疫学研究部（广867-0008 水俣市浜4058-18）
8非会員 工修 九州大学大学院 工学府海洋システム工学専攻（广819-0395 福岡市西区元岡744）

\begin{abstract}
Two kinds of in-site measurement of mercury transport and transformation were attempted in Minamata Bay. First, we conducted highly-frequent (weekly) water sampling for mercury speciation in sea water with continuous current measurement at an observation tower during summer season. Second, monthly water sampling with measuring vertical profile of grain size distribution by LISST-100X at three stations in the bay was carried out.

As a result of this research, the followings are clarified: i) Particulate and dissolved total mercury (T$\mathrm{Hg}$ ) in bottom layer was higher than that in both surface and middle layers; ii) Negative correlation between dissolved T-Hg and methylmercury ( $\mathrm{MeHg}$ ) was shown; iii) Annual particulate T-Hg and $\mathrm{MeHg}$ transport from Minamata Bay to the Yatsushiro Sea was estimated as $6 \mathrm{~kg}$ and $0.05 \mathrm{~kg}$, respectively; iv) Vertical variation of grain size distribution of SS was not shown in winter, but significantly done in summer; and v) It is possible that source of mercury in bottom layer and surface layer is different.
\end{abstract}

Key Words : mercury, methylmercury, suspended solid, grain size distribution, Minamata Bay

\section{1. はじめに}

周知のように，水俣湾を中心とする八代海沿岸で発 生した水俣病の原因物質であるメチル水銀は，化学工 場におけるアセトアルデヒド精製過程で触媒として使 用された無機水銀 $\left(\mathrm{Hg}^{2+}\right)$ が変化した人為的起源によ るものであった ${ }^{1,2)}$. 一方，自然環境中においても無機 水銀がメチル水銀化するメチル化過程，また逆にメチ ル水銀が無機化する脱メチル化過程が存在している3. 例えば，バクテリアに含まれるメチルコバラミン（メ
チルB12）によりメチル水銀が産生される生化学的な 過程や，日射 (紫外線) によりメチル水銀が分解され る光化学的な過程などがそれらに該当する. 通常は, 無機水銀の5\%程度がメチル化すると考えられているが, 有機污濁，塩酸酸性の土壌污染，高濃度の無機水銀污 染などがある場合にはその割合は大きくなると考えら れている，したがって，海域におけるメチル化と脱メ チル化の過程は, 塩分, 水温, 溶存酸素濃度, 酸化還 元電位, 栄養塩 - 有機物濃度, 溶存炭素濃度などの数 多くのファクターにより影響を受けると考えられる. しかしながら，現状ではそれらを普遍的に表現してい 
るモデルはない，また，対象とする場により，支配的 な過程も異なることが予想される.

さらに，海水中の水銀は，流れにより移流・拡散す ることに加えて，大気一海水間，ならびに底泥一海水 間での交換などの物理的過程によっても分布が変化す る.また，無機水銀，メチル水銀ともに溶存態と懸濁 態として水中に存在しており, 懸濁態については浮遊 懸濁物に付着しているため, 底質の再懸濁・沈降過程 によってもそれらの分布が影響を受けることになる.

したがって，海洋や沿岸域における水銀の動態につい ては, 流れ場と底質輸送を解く流体力学的なモデルと 水銀のメチル化・脱メチル化過程を解く生物地球化学 的なモデル結合した数值モデルの開発が進められてい $3^{4), 5)}$. 加えて, 水銀のソースとして人為的なポイント ソースの他に, 大気中からの沈降や流域のノンポイン トソースからの流入なども考えられることから，気象 モデルや流域モデルとの結合も将来的には必要になる と予想され，すでにそのようなモデルを視野に入れた 研究も諸外国では始まっている ${ }^{5), 6,7)}$.

著者らの研究グループは，過去に人為的な水銀污染 が起こり，現在では高濃度水銀 (>25ppm, dry weight) を含む底質が浚渫されて安全な状態になっているもの の自然界のバックグラウンド濃度 (底泥中の総水銀濃 度 : 0.1ppmオーダー, dry weight) と較べると若干高い濃 度（<10ppm, dry weight）を示寸水俣湾において，2006 年以降概初毎月1回の海水サンプリング(定期観測)を 現在まで継続して実施している。これまでに総水銀

(無機水銀十メチル水銀) とメチル水銀の季節変化の 特徴とメチル化一脱メチル化過程に対して溶存酸素濃 度と塩分が高い相関性を示すことが明らかにされてい る ${ }^{8)}$ 。また, ADCPを使用した連続観測結果から, 流速 とSS濃度を測定し，併せて実施した水銀の鉛直分布 データから懸濁態総水銀のフラックスを推定し，水俣 湾から八代海へ向かって水銀が流出している傾向の存 在を示している9 100,11). このことは, 八代海と水俣湾 における底質中の水銀濃度分布から得られている水俣 湾をソースとして八代海へ拡散している状況 ${ }^{12)}{ }^{13)}$ と整 合していた。しかしながら，これまでの観測では，䀣 濁態のメチル水銀について測定されておらず，メチル 水銀の八代海への流出量は不明であった。 また，懸濁 態の水銀については，付着濃度が粒径に依存して変化 することが予想されるものの, SSの粒径分布と微量水 銀濃度の関係については知見がない状態であった。

そこで，2010年夏季にADCP連続観測を実施し，そ れに併せて懸濁態メチル水銀濃度を含む水銀濃度の鉛 直分布測定を毎週実施した，その際，底面から $10 \mathrm{~cm}$ 位 置における海水を採水する装置を新たに導入し, 底層 の分布の精度を向上させた．さらに，2010年10月から 毎月の定期観測時に，現場でSSの粒径分布を測定でき るレーザー回折式粒度分布測定器LISST-100Xを導入し

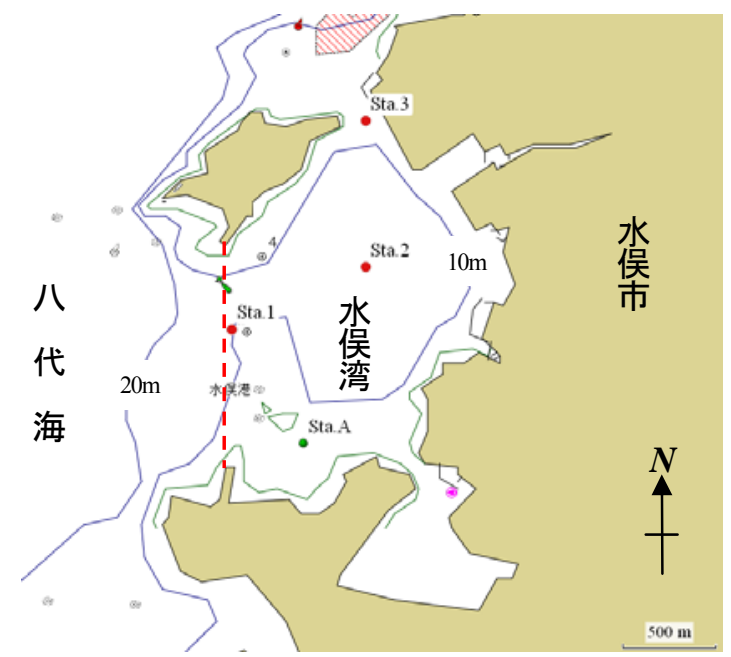

図-1 観測地点

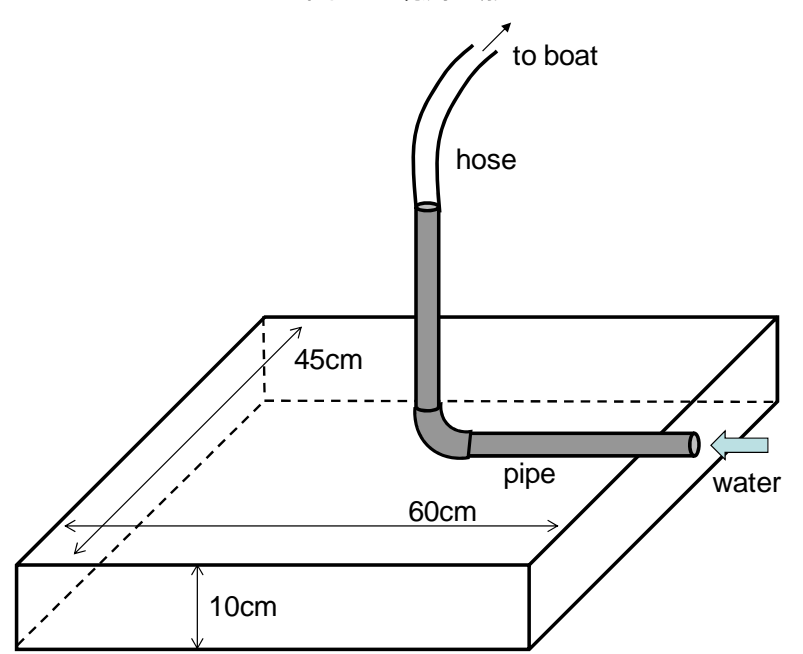

図-2 底面直上水の採水器の概略図

て，海水サンプリングと同時並行にSS粒径分布の鉛直 分布を測定した．本論文では，これらの新しい測定か ら得られた知見を報告する.

\section{2. 現地観測の概要}

\section{（1）連続観測について}

2010年7月20日〜2010年10月2日の75日間に，図-1に 示すSta.A（北緯 $32^{\circ} 11.072^{\prime}$ ，東経 $130^{\circ} 22.084^{\prime}$, 平均水深 $13.5 \mathrm{~m}$ ）に設置された観測櫓において，ADCP（Nortek 社製，Aquadopp Profiler 1000kHz）を1台海底設置し流 速分布の連続測定を行った. サンプリング間隔は15分, 測定層厚，ブランクおよびヘッドの海底面からの高さ はそれぞれ $100 \mathrm{~cm}, 50 \mathrm{~cm}, 0 \mathrm{~cm}$ であった. よって，第 1 層（最下層）の中心位置は海底面上 $100 \mathrm{~cm}$ となる。

海水中水銀濃度（溶存態総水銀・メチル水銀，懸濁 態総水銀・メチル水銀の4種類）とSS濃度の鉛直分布 の時間変動を知るために，概敉 1 週間間隔（小潮・大 潮時に合わせた）の採水サンプリングを行った。採水 は，下げ潮最強時の前後30分間に実施された。観測櫓 
に観測船を横付けし，櫓上に木製の踏み台を設置した 後, その上からポンプ式採水器によりサンプリングを 行った. 採水器のホース先端に多項目水質計YSI6600

(YSIナノテック社製) を取り付け，採水深度を厳密

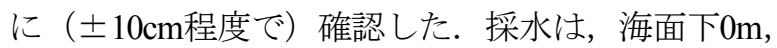

$2 \mathrm{~m}, 4 \mathrm{~m}, 6 \mathrm{~m}, 8 \mathrm{~m}, 10 \mathrm{~m}$ ，ならびに海底面から $1 \mathrm{~m}$ と $10 \mathrm{~cm}$ の計8層について行い, 海底面付近までの詳細な 鉛直分布を求めた。海底面上 $10 \mathrm{~cm}$ 位置の海底直上水の 採水には，2010年より新たに導入した採水器（図-2） を使用した。これは，アクリル製の箱形の台に塩ビパ イプを取り付けることで，底泥の巻き上げを最小限に 押さえつつ, 船上から確実に海底面上 $10 \mathrm{~cm}$ 位置に採水 口を設定できるものである. この採水器をホース先端 部に取り付け, 海底へ静かに定着させた後に, 着地に 伴う再懸濁の発生がないこと確認してサンプルを採取 した．サンプルは，観測終了直後に国立水俣病総合研 究センターの実験室へ運搬し，水銀の測定がなされた。 総水銀は還元気化原子吸光光度法（循環式一改良型） でメチル水銀はジチゾン抽出-ECG-GLC法により測 定された ${ }^{3)}$. 溶存態と懸濁態は，孔径 $0.45 \mu \mathrm{m}$ の濾紙で 濾過した海水と濾紙上に残った懸濁物によりそれぞれ 測定された.

さらに，採水と並行して，多項目水質計（アレック

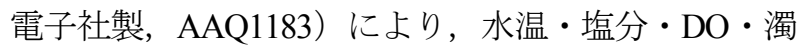
度などの鉛直分布を測定している。

\section{（2）定期観測について}

2006年3月以降，図-1に示寸Sta.1（北緯32 $11.4^{\prime}$ ，東 経 $130^{\circ} 22.84^{\prime}$, 平均水深 $22 \mathrm{~m}$ ) , Sta.2 (北緯 $32^{\circ} 11.58^{\prime}$, 東経 $130^{\circ} 22.30^{\prime}$ ，平均水深 $14.9 \mathrm{~m}$ ），およびSta.3（北緯 $32^{\circ} 12.00^{\prime}$, 東経 $130^{\circ} 22.30^{\prime}$, 平均水深 $\left.13.5 \mathrm{~m}\right)$ の3地点に おいて，海水中水銀濃度の鉛直分布を測定するために， 概放月1回（大潮期）のペースで採水サンプリング を継続している．採水は下げ潮最強時の前後60分間で 実施している．観測地点に観測船を停泊させ，アン カーを打った後に前述のポンプ式採水器によりサンプ リングを行っている. なお, 採水水深は海面下 $0 \mathrm{~m}$, $6 \mathrm{~m}, 10 \mathrm{~m}$ ，ならびに海底面から $1 \mathrm{~m}$, 海底から $10 \mathrm{~cm} の$ 計5層（Sta.3のみ $10 \mathrm{~m}$ を除く4層）である.

さらに，連続観測と同様に，多項目水質計による水 温・塩分・DO・濁度などの鉛直分布を測定している. 2010年10月からは，LISST-100X（SEQUOIA社製）を 用いてSSの粒度分布の鉛直分布測定を始めた. LISST100Xは，レーザー回折の原理により水中の浮遊䀣濁物 質による散乱光の小角度強度分布を記録し，粒径スペ クトルに変換することで測定セル内のSSの粒度分布を 測定するものである. サンプリング間隔を1秒とし， 本体を水平に保ってロープで吊し, 観測船上より人力 で海面から海底に向けてゆっくりと降万す（概ね $1 \mathrm{~m}$ 当 たり6個のサンプリングができる程度）ことで各層の (a)
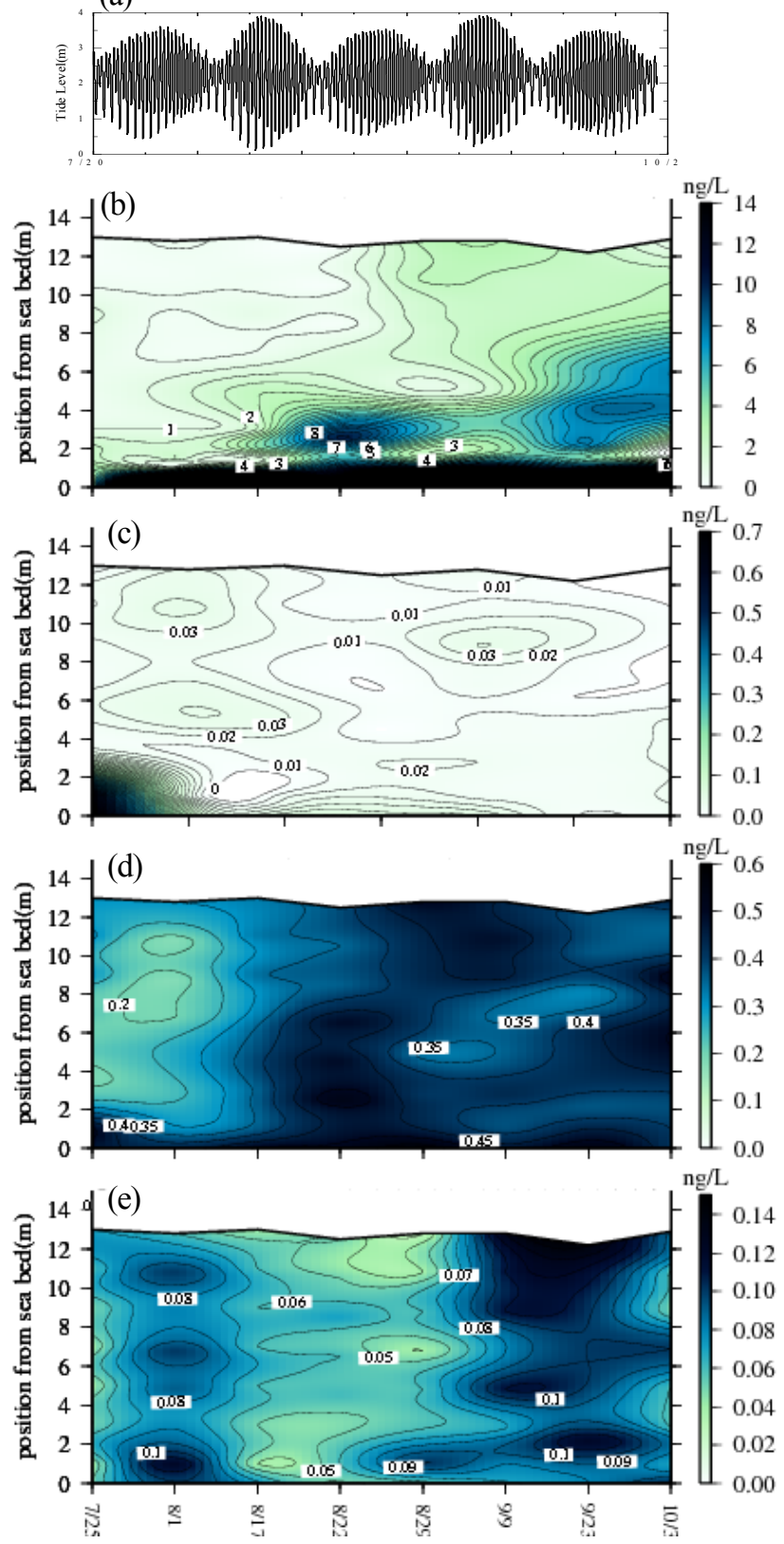

図-3 (a) 潮位変化, (b) 〜 (e) 懸濁態総水銀, 懸濁態メチル水銀, 溶存態総水銀, 溶存態メチル水銀の鉛直分布の時間変化

SSの粒度分布を得ている. 使用機器の粒径測定レンジ は2.5 $\mu \mathrm{m}$ から $500 \mu \mathrm{m}$ であり，これを32サイズに対数分 割した各分画に入る懸濁物質の体積濃度 $(\mu \mathrm{L} / \mathrm{L})$ が測定 可能となっている. よって, SS濃度も体積濃度で測定 される.

\section{3. 観測結果と考察}

（1）連続観測について

a）水銀の鉛直分布の時間変化

観測期間中の潮位変化と, 懸濁態総水銀, 懸濁態义 
チル水銀, 溶存態総水銀, ならびに溶存態メチル水銀 の濃度分布の時間変化をそれぞれ図-3 (a)〜 (e) に示す。 総水銀については, 䀣濁態, 溶存態ともに底面付近で 高い傾向があり，底質からの再懸濁や溶出によるもの と考えられる．7/25から8/1にかけて溶存態総水銀の濃 度は低いが，溶存態メチル水銀の濃度は高くなってい た. 一方，8/17から8/29にはその逆の傾向であった. このような溶存態の総水銀とメチル水銀の間で負の相 関が見られるという結果は，2009年夏季に行った連続 観測結果 ${ }^{9}$ と一致していた。一方，今回初めて懸濁態 に関しても同様な比較ができたが，溶存態とは異なり 強い相関性は見られなかった。 なお，前報にも記載し たとおり，環境基準ではメチル水銀などのアルキル水 銀が検出されないこととなっているが，公定法では検 出限界以下の極めて低いメチル水銀が今回採用した高 精度な測定法により測定されたものである.

\section{b) SSの輸送について}

次に, ADCPから得られた流速分布より海底面から $1 \mathrm{~m}$ 毎のSSフラックスを求めた. 過去の同様な調查にお いては，ADCPが記録する反射強度データからSS濃度 を推定していたが，水俣湾においてはSS濃度が小さい こともあり両者の相関性があまり高くない，そこで， 今回は採水サンプルから得られたSS濃度データを使用 した.この場合，データは採水時しか存在しないため, その間は線形補間した. SSフラックスを流向により 16 方位に分類し，測定時間間隔（900秒）と層厚 $(1 \mathrm{~m})$ を掛けて，正反対方向同士の収支をとり，それを水深 積分して単位幅当たりのnetのSS輸送量を算定した

（図-4）. ADCPは水表面付近で超音波の反射が起こ り，水深の1割程度において正確な值が得られない

(サイドローブ干渉)。したがって, 最低潮位時の水 深に対する9割範囲内に含まれるデータのみを用いた ため，今回の観測では海底から $9 \mathrm{~m}$ 層までのデータを用 いている．過去の観測結果 ${ }^{9)}$ と同様にnetのSS輸送量は, 北向きと西向きに大きく分かれていたが，西向き成分 の卓越性が顕著であった。

\section{c）懸濁態総水銀の輸送について}

次に，懸濁態総水銀濃度（単位懸濁物質量あたり， $\mathrm{mg} / \mathrm{kg}$ ）の時間変化を線形的に補間して, SS濃度, 流 速，ならびに流向を用いることで懸濁態総水銀フラッ クスを求めた. SSの場合と同様に，観測期間中におけ る懸濁態総水銀輸送量（単位幅当たり, net）を算定し た（図-5）。卓越する輸送方向はSSの場合と同様で あった. しかし，その分布はSS と比較して完全には相 似になっていない，これは，水銀濃度とSS濃度の時間 変化特性の違いから生じたものであり, 前報) 同様に 水銀測定を可能な限り高頻度に行うことが水銀輸送量 の推定において重要であることを再確認した.

さらに，懸濁態総水銀輸送量から，西部湾口（図-1 の赤い破線）を通って水俣湾から八代海へ 1 年間に流

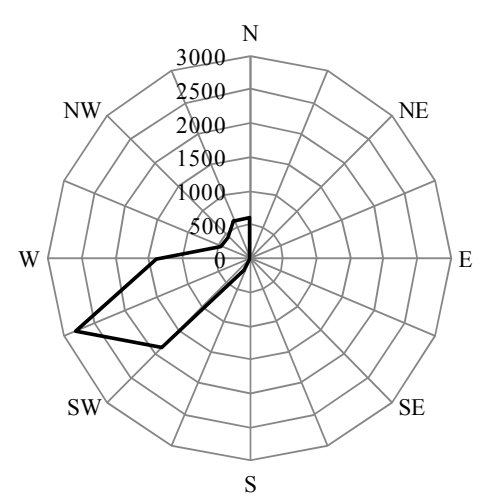

図-4 観測期間中のSSのnet輸送量[単位幅当たり, kg/m]

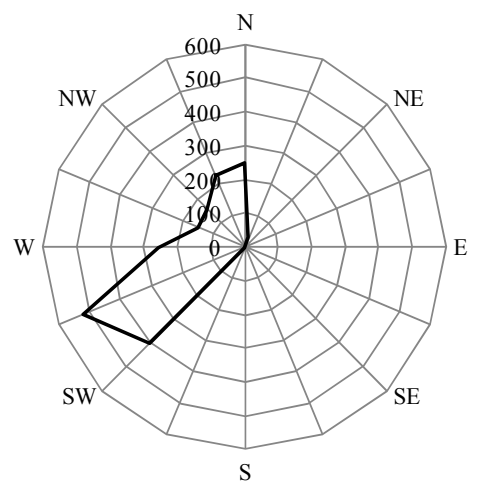

図-5 観測期間中の䯚濁態総水銀のnet輸送量[単位幅当たり, $\mathrm{mg} / \mathrm{m}]$

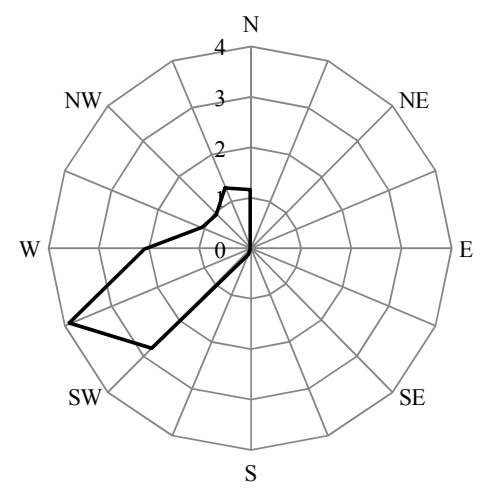

図-6 観測期間中における懸濁態メチル水銀のnet輸送量[単 位幅当たり, $\mathrm{mg} / \mathrm{m}$ ]

出する輸送量を推定した．まず，図-5で示された輸送 量の方位分布から西，西南西，南西成分（ただし，西 北西，北西，北北西に関しては，裸瀬の影響を考え除 いた）を西方と南方に成分を分解し，西方成分の輸送 量のみを足し合わせた。これに西部湾口の幅

（1200m）を掛け，1年間に引き伸ばすことで換算した. その結果, 年間流出量は6.0 kg程度と算定された。 これ は前報9)と同程度であり, 䀣濁態総水銀の流出量は概 ねこの程度のオーダーであるものと考えられる.

\section{d）懸濁態メチル水銀の輸送について}

今回は懸濁態のメチル水銀濃度のデータが得られた ことから，懸濁態総水銀と同様の方法でnetの輸送量を 推定した（図-6)．方向分布は，総水銀の場合と同様 にSS と総水銀とも完全な相似ではなかった。これは, 
(a)

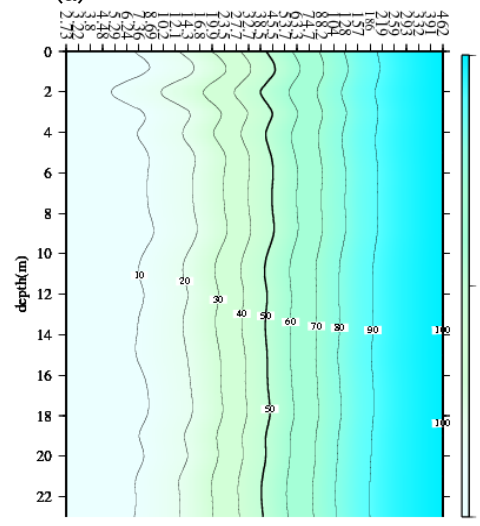

(d)

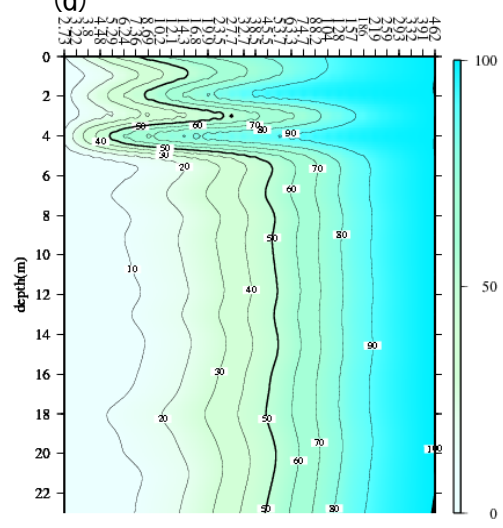

(b)

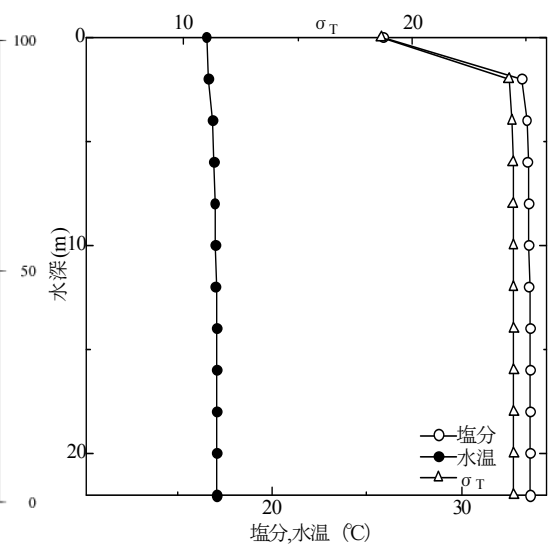

(e)

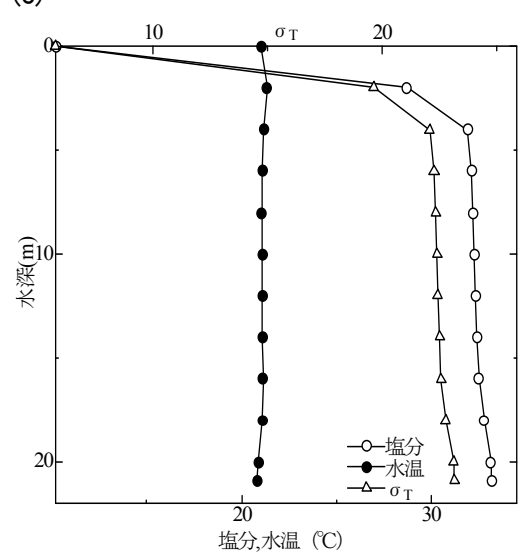

(c)

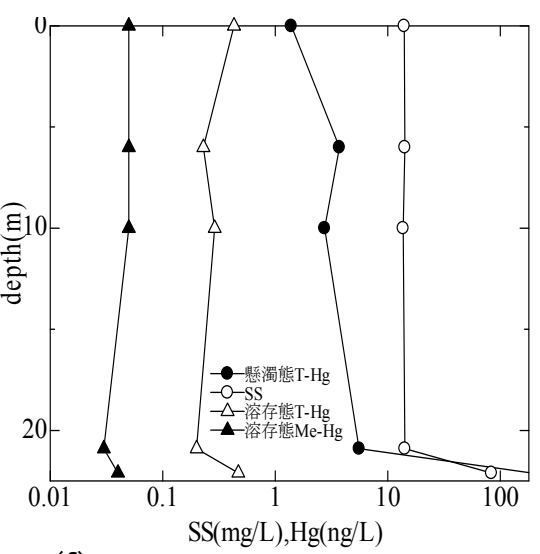

(f)



図-7 (a) 2010年12月22日のSS粒度分布の鉛直分布, (b) 同日の海洋構造, (c) 同日のSSと水銀の鉛直分布, (d) 2011年6月18日 のSS粒度分布の鉛直分布, (e) 同日の海洋構造, (f) 同日のSS と水銀の鉛直分布

総水銀中のメチル水銀の割合が一定でなかったために 生じたものである.また，年間のメチル水銀輸送量は $0.05 \mathrm{~kg}$ 程度と算定された. これは総水銀と比べると 100 分の1程度であり，濃度の違いと同程度の差であった。

ここで得られた懸濁態総水銀と懸濁態メチル水銀の 年間輸送量は，過去に数值モデルにより推定された值

(それぞれ $150 \mathrm{~kg}$ と $0.5 \mathrm{~kg})^{14)}$ と比べるとオーダーが異 なっていた. 数值モデルにおいて水銀濃度データの不 足や底質の再懸濁過程が暴浪によるもののみであると いう仮定の問題があること，今回の観測においてSS濃 度の推定精度の問題や採水サンプリングの間の水銀濃 度の変動が未知であることなどから，現状ではどちら の精度が高いかは判断しづらい. しかし，2009年の観 測9で得られた総水銀輸送量と概ね同程度であった事 実から，観測で得られた值の信憑性が高いとも考えら れそうである.より精緻な観測が必要といえる.

\section{（2）定期観測について}

本論文では，LISST-100Xにより粒度分布を測定し始 めた2010年10月以降について, 粒度分布と水銀濃度等 との関係について考察する. 冬期の混合期を代表して 2010年12月22日，夏季成層期を代表して2011年6月 18
日の両日についての結果を以下に示す。なお，湾内3 地点の観測結果の特徵は同じ観測日については概ね同 一であったことから，Sta.1の結果のみを示す．両日の LISST-100Xにより測定されたSSの粒度分布（加積通過 率，\%）の鉛直分布をそれぞれ図-7（a），(d)に示す. 図中の太い実線は $50 \%$ の線であり中央粒径の分布を示 している. 冬季の粒度分布は水深方向に顕著な違いが 見られない. 一方, 夏季には表層 (海面 $6 \mathrm{~m}$ 程度) と それ以深では分布がかなり異なっており，粒径の細か い粒子が表層に多いことが分かる．これは紙幅の都合 で割愛した2011年7月17日においても確認されていた.

次に, 図-7(b)，(e)に両日の海洋構造（塩分，水温， 密度 $\left(\sigma_{\mathrm{T}}\right)$ ）の鉛直分布を示す。また, 図-7 (c), (f) に両 日のSS と水銀 (溶存態総水銀・メチル水銀, ならびに 懸濁態総水銀）の鉛直分布を示す. 6月18日について は，表層に淡水が流入しているのが分かる。これは， 観測日の5日前からの周辺地域の累積降雨量が400mm 程度に達しており，河川水の流入があったためである. なお，7月についてはこのような降雨はなかったが， 表層（海面から6m程度まで）とそれ以深との間に水温 差 $2^{\circ} \mathrm{C}$ と塩分差 3 程度の違いが見られていた. これらの 粒径の細かい浮遊物の起源は，周辺の河川であると考 
えられるが，水俣湾周辺には比較的大きな河川は2級 河川の水俣川と米之津川があるものの，流量の情報な どが不足しているため，ここでは明確なことはいえな い. SS と水銀については，両日とも海底直上で高い值 を示しており，水俣湾の懸濁態総水銀の起源が底質か らの再懸濁であることを示している．しかし，6月に ついては表層でも両者が高くなっており，この起源に ついては前述の通り物理的には河川と考えるのが妥当 であるが，河川水の総水銀濃度が底層と同程度に高い とは考えにくいことから他の起源の可能性も残される. この点に関しては, 情報が不足しているので今後の調 查で明らかにしていく必要がある.

\section{4. まとめ}

本研究では，水俣湾においてこれまでに実施してき た水銀の形態と輸送量の調查について, 新たな観測機 器を導入して改良を行った. 水銀の輸送については, 過去の調查と同様に水俣湾から外海である八代海一向 う輸送があることが示された．今回は，初めて縣濁態 メチル水銀の濃度の測定を行い，その輸送量について も推定することができた.

また，LISST-100Xを導入することで毎月実施してい る定期水銀調查において懸濁態の粒度との相関性を調 べるためのデータ取得が可能となった．現段階では， 半年分程度のデータしか蓄積されていないため, 明確 な相関を調べるには至っていないが，今後の継続調査 により相関性を明らかにすることが可能となるであろ う.

本研究グループでは, 最終的に水俣湾とその周辺海 域における水銀動態をシミュレートする数值モデルの 開発を一つの目標にしている. 今後の観測データの蓄 積により, 数值モデルの精度評価や生物地球化学的反 応のモデル化を行っていく予定である.

謝辞: 本研究は, 環境省国立水俣病総合研究センター による平成22年度，ならびに23年度総合的水銀研究推 進事業（水俣湾沿岸域に放出された残留水銀の動態予 測 : コンピュータ・シミュレーションによる数值モデ ルの開発. 研究代表者 : 矢野真一郎) の援助により実 施された. ここに記し，深甚なる感謝の意を表する.

\section{参考文献}

1) 赤木洋勝: 有機水銀污染一水俣病のその後と海外の実情, 病態生理, Vol.14, No.8, pp.597-604, 1995.

2) 西村肇, 岡本達明 : 水俣病の科学, 日本評論社, 2001 .
3）（財）日本公衆衛生協会 : 水銀污染対策マニュアル, 2001.

4) Zagar, D., Petkovsek, G.., Rajar, R., Sirnik, N., Horvat, M., Voudouri, A., Kallos, G. and Cetina, M.: Modelling of mercury transport and transformations in the water compartment of the Mediterranean Sea, Marine Chemistry, Vol.107, pp.64-88, 2007.

5) Harris, R., and Pollman, C., Landing, W., Hutchinson, D., Evans, D., Axelrad, D., Morey, S.L., Sunderland, E., Rumbold, D., Dukhovskoy, D., Adams, D. and Vijayaragahavan, K.: Mercury cycling, bioaccumulation and human exposure in the Gulf of Mexico, Proc. of 10th International Conference on Mercury as a Global Pollutant, p.127, 2011.

6) Zagar, D., Knap, A., Warwick, J.J., Rajar, R., Horvat,. M. and Cetina, M.: Modelling of mercury transport and transformation processes in the Idrijca and Soca river system, Science of the Total Environment, Vol.368, pp.149-163, 2006.

7) Knightes, C.D.: Development and test application of a screeninglevel mercury fate model and tool for evaluating wildlife exposure risk for surface waters with mercury-contaminated sediments (SERAFM), Environmental Modelling \& Software, Vol.23, pp.495-510, 2008.

8) Matsuyama, A., Eguchi, T., Sonoda, I., Tada, A., Yano, S., Tai, A., Marumoto, K., Tomiyasu, T. and Akagi, H.: Mercury Speciation in the Water of Minamata Bay, Japan, Water, Air and Soil Pollution, Vol.218, pp.399-412, 2011.

9) 矢野真一郎, 多田彰秀, 田井明, 矢野康平, 井村一樹, 藤 原竜二 : 水俣湾における高頻度な水銀採水調査による微 量残留水銀輸送量の測定, 土木学会論文集B2（海岸工 学), Vol.66, No.1, ,pp.961-965, 2010.

10）矢野真一郎, 多田彰秀, 押川英夫, 中村武弘, 赤木洋勝, 松山明人, 富安卓滋, Rudolf Rajar, Milena Horvat : 水俣 湾における底泥動態の現地観測, 海岸工学論文集, 第50 巻, pp. 1006-1010, 2003.

11) 矢野真一郎, 多田彰秀, 松山明人, 押川英夫, 富安卓滋, 赤木洋勝, 中村武弘, Rudolf Rajar, Milena Horvat : 水俣 湾における微量残留水銀動態に関する現地観測, 海岸工 学論文集, 第 51 巻, pp. 1216-1220, 2004.

12) Tomiyasu, T., Nagano, A., Yonehara, N., Sakamoto, H., Rifardi, Oki, K. and Akagi, H.: Mercury contaminant in the Yatsu-shiro Sea, south-western Japan : spatial variations of mercury in sediment, Sci. Total Environ., Vol. 257, pp. 121-132, 2000.

13) Tomiyasu, T. , Matsuyama, A., Eguchi, T., Fuchigami, Y., Oki, K., Horvat, M., Rajar R. and Akagi, H.: Spatial variations of mercury in sediment of Minamata Bay, Japan, Sci Total Environ., Vol.368, pp. 283-290, 2006.

14) Rajar, R., Zagar, D., Centina, M., Akagi, H., Yano, S., Tomiyasu, T. and Horvat, M.: Application of three-dimensional mercury cycling model to coastal seas, Ecological Modelling,Vol.171, pp. 139-155, 2004.

(2011. 9. 30受付) 